\title{
Inland traditional capture fisheries in the Congo Basin: Introduction
}

Pêches traditionnelles dans les eaux intérieures du Bassin du Congo:

introduction

Edmond Dounias and Takanori Oishi

\section{OpenEdition}

\section{Journals}

Electronic version

URL: http://journals.openedition.org/ethnoecologie/2882

DOI: 10.4000/ethnoecologie.2882

ISSN: 2267-2419

\section{Publisher}

Laboratoire Eco-anthropologie et Ethnobiologie

\section{Electronic reference}

Edmond Dounias and Takanori Oishi, «Inland traditional capture fisheries in the Congo Basin: Introduction », Revue d'ethnoécologie [Online], 10 | 2016, Online since 31 December 2016, connection on 10 December 2020. URL : http://journals.openedition.org/ethnoecologie/2882 ; DOI : https:// doi.org/10.4000/ethnoecologie.2882

This text was automatically generated on 10 December 2020 .

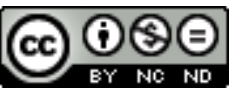

Revue d'ethnoécologie est mis à disposition selon les termes de la licence Creative Commons Attribution - Pas d'Utilisation Commerciale - Pas de Modification 4.0 International. 


\title{
Inland traditional capture fisheries in the Congo Basin: Introduction
}

\author{
Pêches traditionnelles dans les eaux intérieures du Bassin du Congo : \\ introduction
}

Edmond Dounias and Takanori Oishi

1 In these current times marked by tremendous shifts challenging the future of our planet - exponential population growth, environmental degradation and biodiversity loss, climate change, expanding urbanization - maritime as well as inland aquatic resources are constantly gaining credence in the plans of action set up in the international management and development policy. Their food values are brandished as one of the most promising means to reduce poverty and hunger while ensuring that all human beings can fulfill their potential in dignity and equality and in a healthy environment ${ }^{1}$.

2 In this respect, after decades of long-standing policies encouraging the industrialization of fisheries and neglecting the small-scale sector (see for instance Cycon 1986), the importance of sustaining small-scale fisheries is being increasingly recognized (Pauly 1997). Nevertheless this recognition goes along with a disturbing awareness that traditional capture fisheries are poorly known and that there is a dearth in research dedicated to inland aquatic resources, especially with regard to their availability and to the sustainability of their harvesting. The desired expansion of artisanal fisheries in developing countries has now given rise to fears of resource depletions, threatening local livelihoods and the nutritional status of low-income households (World Humanities Action Trust 2000).

3 So far, it must be acknowledged that decision makers decide on issues at stake without having in hand the consistent data that are needed to support their decisions. In one of the most recent studies dedicated to traditional inland fisheries, De Graaf et al. (2015) point out the inaccuracy in the estimates of the worldwide fish production ensured by inland fisheries. Most importantly, statistics are nearly absent for critically important tropical areas like the Amazon and the Congo Basin. Hundreds of million people are certainly involved in activities relating directly to capture, processing and sale of fish. 
Citing FAO, Allison and Ellis (2001) estimate that $95 \%$ of them live in developing countries. Still, almost nothing is known about the ecology of freshwater fisheries (Chapman 2001) and about the contribution of fish to the livelihoods of non-professional and parttime fishersfolks.

The Congo river is the second largest forest river in the world after the Amazon. These two rivers are home for more kinds of fishes than other rivers altogether and both exhibit unequalled rates of endemism (Roberts 1973). But when compared to what is known in the Amazon Basin, our knowledge of fish and shellfish ecology in the Congo Basin is dramatically fragmentary (Chapman 2001). The Congo Basin exhibits endemic and incredibly diverse aquatic faunas. The rainforest regions of Western and Central Africa host $85 \%$ of the nearly 3,300 species that have been described in the African continent (Chapman 2001, Paugy et al. 2011). Ichthyologists agree to estimate that several hundreds of new fish species are yet to be discovered in this continent, and the lack of knowledge is even worse for non-fish aquatic faunas. The presence of lakes and swampy depressions in the upper course of the Congo river induces smaller amplitudes in water-levels compared to the Amazon but the Congo Basin is characterized by many more rapids and waterfalls that cause strong seasonal fluctuations that result in a juxtaposition of extremely diverse aquatic microhabitats.

5 This special issue does not pretend to fill this worrying gap in knowledge. More modestly but yet importantly, it aims to raise awareness on the extent of our ignorance about the biocultural values and functions of traditional inland capture fisheries in the Congo Basin. The four case studies presented in this issue all address rainforest dwelling peoples of Cameroon and Republic of Congo whose livelihoods do not exclusively depend on fishing. Our goal is to bring light on the multifaceted thus complex nature of Central African wild fisheries and to stress that they constitute only one component of broader and extensive land-use strategies that are multipurpose in essence. To paraphrase LéviStrauss (1964), fish are not only good to eat (or to make money with) they are also good to think with. Fishing mediates the biocultural interactions between these parttime fisherfolks and their natural and supernatural environments. However, management and development agencies persist to ignore the non-economic and less materialistic dimensions of inland capture fisheries. This unawareness has led to the emergence of counter-intuitive ideas about these fisheries and in fine their absence or, to say the least, neglected role in the worldwide agenda for sustainable development.

6 The first paper proposed by Edmond Dounias and collaborators is entitled "The safety net role of inland fishing in the subsistence strategy of multi-active forest dwellers in southern Cameroon". By describing in details the extremely diversified art of fishing of the Mvae and the Ntumu, two Fang speaking groups of small-scale farmers living in the Ntem watershed, Dounias and collaborators wish to emphasize the unobtrusive but fundamental role played by small-scale wild fisheries in the livelihoods of these nonprofessional fisherfolks. Local ichthyological knowledge and understanding of the dynamics of inland water ecosystems that are driven by seasonal fluctuations in water level have jointly shaped an incredibly diverse corpus of fishing practices.

7 Taking advantage of an extremely vascularized hydrographic network and a multitude of aquatic microhabitats, these practices ensure a continuous procurement of fish all over the year and grant a precious flexibility to the land-use system of these forest peoples. Years follow one another but do not look alike. The complementarity of fishing practices always authorizes adjustments in response to constant change and in fine ensures a 
continued provision of aquatic food resources. Flexibility provides latitude to modify the contribution of fish to the local diets in response to opportunities and constraints affecting the other domains of production (farming, hunting, gathering, salaried work).

Mvae and Ntumu inland capture fisheries are a safety net that prevents from uncertainties in food supply, and that is a warranty of food security. Dounias and collaborators also insist on the primordial fact that inland capture fisheries among nonprofessional fisherfolks are not in the exclusive and expert hands of adult-male fishers; on the contrary, they involve equally all the members of the community, independently of gender and age.

9 To conclude, Dounias and collaborators seek to contradict the consensual discourse that small-scale fisheries and rural poverty are intimately correlated. They call upon development agencies to conceptualize their interventions in terms of theirs effects on livelihood systems, instead of assessing specific income-generating activities in isolation from or, worse, in opposition to other activities within these multipurpose land-use strategies.

The second paper is authored by Sandrine Gallois and Romain Duda. As explicitly announced in the title of their paper "Beyond productivity: The socio-cultural role of fishing among the Baka of southeastern Cameroon", Gallois and Duda do not tackle the economic side of wild fisheries but rather decide to introduce various social and cultural aspects of fishing activities among the Baka, a group of African hunter-gatherers living in southeastern Cameroon, in close interrelationships with small-scale Bantu farmers.

11 In the first part of their paper, the authors analyze the place taken by fishing activities in Baka livelihood, productivity, and diet. Based on their careful and systematic monitoring of daily activities (including estimates of time allocation and quantities of harvested resources), Gallois and Duda draw an enlightening picture of the involvement of the Baka into fishing relatively to their many other daily activities. Baka fishery appears anecdotal when the biomass of captured fish is compared to that of terrestrial fauna obtained from hunting. Fish should be seen as a complementary resource providing animal protein in periods of bushmeat shortage. The potential role of fish as a means to moderate the currently unsustainable trade of bushmeat remains a very challenging and burning research topic to address.

12 The second section of the paper details the ecological knowledge and practices related to fishing activities. Most importantly, they consider gender involvement into fishing activities and notice that Baka men and women do not use the same fishing techniques, the same ecological settings, and do not target the same fishes. By contrast to cynegetic activities that are predominantly carried out by men, fishing activities are first and foremost performed by women, who are generally assisted by children. Gallois and Duda point out those Baka children acquire knowledge about the most salient fish resources from a very early age, and that fishing expeditions are fundamental channels of children's education.

13 By looking at the social and cultural grounds of fishing in the last section of their paper, Gallois and Duda wish to emphasize that fishing is much more than just a subsistence activity. They focus on the emblematic dam and bail fishing, which is a collective and female fishing activity. In the absence of men, dam fishing is a necessary occasion for women to share their personal problems, particularly with regard to sexuality, to consult the elderly women and to collectively work out conflicting situations. Dam fishing 
contributes to the subtle equilibrium of power between genders and, in so doing, to the social cohesion of Baka society as a whole.

The third paper is authored by Marion Comptour and collaborators and is entitled "Pond fishing in the Congolese cuvette: a story of fishermen, animals, and water spirits". Comptour and collaborators focus on one fishing method in particular, pond fishing, carried out by the Likouba fishermen in the region of Mossaka in the Republic of Congo. The Likouba excel in this collective fishing method that consists in scooping out water from the pools that persist in the floodplain at the end of the dry season, after that water has receded. Although concentrated on a short period of time, the capture the fish and non-fish aquatic fauna that have sought refuge in these pools is highly productive and sold surplus is a reliable source of cash income. Like all other ethnic groups introduced in this special issue, the Likouba are not fulltime professional fishers, but nevertheless use a broad range of fishing methods adapted to the hydrological pattern and other traits of the habitats they fish in, and to the behavior of the fish species they pursue. Water-level fluctuation is, again, the main guidance for the seasonal migration of fish into and out of the floodplain, and pond fishing is planned accordingly.

Comptour and collaborators insist on the cooperation mobilized during pond fishing, which involves a great number of participants, from both genders and all ages. Most importantly, pond fishing involves not only members of the lineage that owns the pond, but as well outsiders lacking ponds on their own. The authors discuss the customary rules of the Likouba that are aimed to regulate the right of access and ownership of these coveted ponds. Still in a recent past, becoming the owner of ponds was a major focus of social competition, yet this collective activity also strengthened social cohesion through collective work. A lineage head controls fisher access to ponds and endorses the role of mediator between the various human and non-human users of the pond.

Comptour and collaborators argue that pond fishing ties relationships between entities animal, human, supernatural - that jointly dig and shape features of ponds, increasing by this means the productivity of this fishery. The authors describe the trophic relationships between animals - fish and non-fish resources that 'give themselves' to the fishers or, more exactly, are given by supernatural entities, but also other animals living near the ponds -, fisher communities, and spirits who are the real owners of the territory and the parents of fish. Permission given to the Likouba fishers to catch the pond resources is pending on a contractual relationship established between the spirits and the ancestor of the lineage, and is contracted under the form of a blood price: in exchange of being authorized to catch fish, the Likouba resign themselves to accept that spirits, sometimes embodied in a crocodile, devour one of their children.

inent of new technologies and a greater involvement into a cash economy have eroded the values and management systems linked to subsistence fishing and weakened the power of the traditional authority. In response to these recent changes, Comptour and collaborators conclude by showing that the new generation of Likouba fishers has elaborated a new regulation system including the payment of a fee to access to the pond, threats of sorcery, moral judgments and the moral obligation to share fish. Aside of its unquestionable economic importance, pond fishing fulfills equally important social and symbolic functions.

18 Comptour and collaborators provide food for thought in the debate questioning the relevance and resilience of subsistence activities in the livelihoods of most tropical rainforest dwellers: These productive activities also embed epistemological, ethical and 
perceptual dimensions that policy makers and management planners would be well advised to pay attention to.

The fourth paper written by Takanori Oshi is entitled Ethnoecology and ethnomedicinal use of fish among the Bakwele of southeastern Cameroon. Oishi describes the wide range of fishing techniques that are implemented by the Bakwele of the lower Dja watershed in southeastern part of Cameroon. Like the Mvae and the Ntumu introduced by Dounias and collaborators, the Bakwele are primarily small-scale farmers who are only part-time fisherfolks and who have similarly elaborated an achieved corpus of knowledge on ichthyofauna and the vascularized hydrographic ecosystem. Like the Mvae and the Ntumu, the Bakwele perceive no clearcut boundary between hunting/trapping and fishing. Instead, they consider inland water networks and terra firma as closely intermingled, up to forming a unique ecotone.

Oishi insists on the intercultural relationships that are amplified around fishing: Local Bakwele fishers work in intelligent synergies with allochtonous fishers who bring a different yet complementary expertise in fishing. Both communities get reciprocal benefits from this cohabitation. Along the same line, Oishi evokes the beneficial properties of the seasonal settlement in fishing camps for unblocking conflicting situations. Residing in seasonal fishing camps has a cathartic effect on the intra and interethnic relationships.

21 Finally, Oishi explores non-food uses of ichthyofauna and elaborates on the important range of food taboos affecting the fish, and their contribution to the Bakwele traditional healing system. The Bakwele attribute utmost importance to aspects of fish - taste as food, role in food taboos, medicinal uses - that are seldom valued from an economic point of view. This allows Oishi to further describe the fundamental influence exerted by fish on the Bakwele's perceptual approach of their surrounding world. Fish are key to understand the overall cultural cognition system of the Bakwele, although fishing does not constitute the salient component of their cash income economy.

Beyond the circumscribed area of the Congo Basin, traditional capture fisheries in the inland waters of other less forested parts of the African continent arise many promising pathways of interdisciplinary reflection bridging past and present. The session on African fishers convened by Veerle Linseele during the 23rd biennial meeting of the Society of Africanist Archaeologists (Toulouse, France, June 2016) and introduced as an ending note in this special issue, was a rare yet stimulating opportunity to strengthen the dialogue between archaeologists and ethnobiologists studying modern day fisheries. This dialogue should help tackling the complexity of human behavior and of human interaction with the natural environment. As stressed by Linseele, looking at modern practices is extremely useful to grasp the complexity of life in the past, and fishing activities certainly played a prominent role in this complexity.

The compendium of articles proposed in this special issue is a gentle invitation for policy makers and management planners to avoid simplistic and sweeping statement and change their views vis-à-vis traditional inland capture fisheries in the African rainforests. By pointing out the gaps in knowledge, caveats for development and challenges for conservation, we hope that this issue will stimulate further research and throw light on the most promising pathways to explore: on the resource side, by broadening our knowledge on the ecology of inland aquatic fauna in this forested part of the African continent; on the fisherfolks side by eliciting the obvious but overlooked 
ethnoichthyological expertise of local fishers and by improving our understanding of the biocultural drivers of these traditional fisheries.

Sectorally-based policies that seek to professionalize fulltime fishers tend to ignore that diversity is an essential feature in the livelihoods of the vast majority of fishing forest dwellers in Central Africa. By taking this major attribute into consideration and by recognizing the seasonal and cyclical complexity of these livelihood strategies, policies should gain in encouraging and facilitating the continuation of part-time fishing in these communities. The seasonality of water level fluctuations and the related richness in inland water microhabitats are key elements valorized by the African rainforest fishers to perform their fishing activities. Mobile and fluctuating fish stocks require from part-time fishers to be geographically mobile. Rather than being an obstacle to development, this extensive mobility and flexibility should be seen as a beneficial means to stock conservation in that the absence of locally-focused fish catches moderates the risk of resource depletion. Far from being the poverty trap consensually denounced by development agencies, traditional inland capture fisheries are a genuine invitation to think poverty alleviation in the tropics differently.

But the undeniable potential of inland capture fisheries should not conceal some real obstacles and mask the limitations of small-scale fishery development. Although fish has for long granted forest people with food security and can certainly be a valuable alternative to costly livestock farming and to depleting bushmeat trade, the sustainability of fishing throughout the Congo Basin remains highly questionable in a context of increasingly critical procurement of animal protein. African demographic pressure, amplified by migrations of various origins - mining, logging, extension of protected areas, agro-industrial plantations, climatic catastrophes, rampant poverty, armed conflicts, local mafias, genocides, bad governance... - will certainly induce an increasing demand for fish; intensification of small-scale fisheries as a means to get minimal resources to survive has already led to the overexploitation and irreversible pollution of many inland waters. The contribution of fish farming is still marginal and its development remains slow, although some species of African fishes are among the most promising candidates for the future of this activity. The forms of control of fishing activities are in upheaval while the resource availability remains largely unknown. Customary rules of access that efficiently used to exert a local control over freshwater resources are jeopardized by more centrally managed policies. But African states meet increasing difficulty in maintaining regulations: environmental-unfriendly and more intensive fishing practices are progressively escaping out of control. Far from discouraging research initiatives, this dark situation should be viewed on the contrary as an ultimate reason for boosting further exploration of the issue.

The guest editors would like to acknowledge the following research organizations for their supportive encouragements in providing a special issue dedicated to the ethnobiology of inland capture fisheries in the Congo Basin: The Center for International Forestry Research (CIFOR), the French National Research Institute for Sustainable Development (IRD), the National Museum of Natural History (MNHN), the Center for Functional and Evolutionary Ecology (CEFE), and Kyoto University. 


\section{BIBLIOGRAPHY}

Allison E.H. \& Ellis F. 2001 - The livelihoods approach and management of small-scale fisheries.

Marine Policy 25: 377-438.

Chapman L.J. 2001 - Fishes of African rain forests. In Weber W., White L.J.T., Vedder A. \&

Naughton-Treves L. (Ed.), African rain forest ecology and conservation: An interdisciplinary perspective. New Haven, Yale University Press: 263-290.

Cycon D.E. 1986 - Managing fisheries in developing nations: a plea for appropriate development. Natural Resources Journal 26: 1-14.

De Graaf G., Bartley D., Jorgensen J. \& Marmulla G. 2015 - The scale of inland fisheries, can we do better? Alternative approaches for assessment. Fisheries Management and Ecology 22: 64-70.

Lévi Strauss C. 1964 - Le cru et le cuit. Paris, Plon, 402 p.

Paugy D., Lévêque C. \& Mouas I. (Ed.) 2011 - Poissons d'Afrique et peuples de l'eau. Marseille, IRD Éditions, $319 \mathrm{p}$.

Pauly D. 1997 - Small-scale fisheries in the tropics: marginality, marginalisation, and some implications for fisheries management. In Pikitch E.K., Huppert D.D. \& Sissenwine M.P. (Ed.), Global trends: fisheries management. Bethesda, Maryland, American Fisheries Society: 40-49.

Roberts T.R. 1973 - Ecology of fishes in the Amazon and Congo Basins. In Meggers B.J., Ayensu E.S. \& Duckworth W.D. (Ed.), Tropical forest ecosystems in Africa and South America: A comparative review. Washington D.C., Smithsonian Institution Press: 239-254.

World Humanities Action Trust 2000 - Fishing for the future. In Governance for a sustainable future. London, World Humanities Action Trust: 37-104.

\section{NOTES}

1. Overarching goal of the United Nations 2030 Agenda for Sustainable Development: http://www.un.org/sustainabledevelopment/development-agenda

\section{AUTHORS}

\section{EDMOND DOUNIAS}

IRD-CIFOR - Centre d'Écologie Fonctionnelle et Évolutive (UMR5175 CEFE)

Campus CNRS, 1919 route de Mende - 34293 Montpellier cedex 5, France edmond.dounias@ird.fr 


\section{TAKANORI OISHI}

Tokyo University of Foreign Studies - World Language and Society Education Centre 3-11-1, Asahi-cho, Fuchu-shi - Tokyo 183-8534, Japan

takanori@tufs.ac.jp 